\title{
用語解説
}

\section{協調フィルタリング（Collaborative filtering）}

我々は社会生活において、自分と趣味が合う人から気に入った映画を推薦してもらったり、趣味の合うグルー プの中の口コミを尊重することが多い。協調フィルタリングとは、そういった口コミの仕組みを体系化し、大量 の情報源からユーザ问けの情報を抽出する手法である。従来は、検索対象となる情報を複数の属性で還元的に表 現し、その属性值の近さを指標にして情報フィルタリングがなされることが多かった。しかし、音楽や映像な ど、人の感性に大きく依存する対象を多变量デー夕に還元することは難しく、検索や推薦の精度を高应るこが 困難であった。そこで、協調フィルタリングは従米の手法を補うものとして、近年注目されている。

協調フィルタリングの運用には、情報を利用する大勢のユーザとそれらの間を仲介するシステムが必要とな る。主な処理は、1) 大勢のユーザの情報利用履歴と嗜好のデー夕の収集、2) ユーザ(の嗜好を表すモデル)間の マッチメイキング、である。通常、最初にユーザに簡単なアンケートに答えてもらって嗜好の初期モデルを獲得 し、それから情報利用の度にそれらへの評価を人力してもらいながら徐々に各ユーザの嗜好モデルを精錬してい く。しかし、ユーザ数が少ないとフィルタリングは機能しないし、情報利用の度に評価を入力しなければならな いのはユーザにとって煩わしい。また、システムは人勢のユーザの情報利用履歴や嗜好デー夕を蓄積するので、 プライバシーの開題がある。これらの問題への対処が現在の重要課題である。

(ATR 知能映像通信研究所 角 康之)

\section{Jini}

Jini*(“ジーニー”と読む)とはLAN 向けの分散システム環境の1つであり，“リソースとユーザの連合体の形 成”を基本理念として Sun Microsystems*, Incにより開発された，Jini は，同社で先に開発されたJava*アプ リケーション環境をネットワーク接繶された複数の機械へ拡張したものと位置付けられ，特にJavaのオブジェ クト移送，インタフェース拈よびセキュリティ機構を活用している。

Jini アーキテクチャでは，人間やブログラム，または他のサービスによって使用されるあらゆるものを‘サービ ス’よぶ. lookup と名付けられた特別なサービスが提供されており，各侍点で利用叮能なリソースを管理する. 一般のサービスは，lookup サービスに望みの機能をまとめたイシタうェンスを渡し必要なりソースを検索する。 リソースはJava オブジェクトとして登録されており，オブジェクト移送とセキュリティ機構によりそれを利朋 するサービスの下で交全に実行される。リソースを提供するサービスの実体は隐蔽されている，新たに接続され たサービスは自動的に lookup サービスに提供するリソースを登録し，この情報を定期的に更新しなければなら ない。この機構により Jini システムの管理者は，着脱するだけでサービスを提供または削除できる。仕様はか詳 細は[1]を参照されたい。

その柔軟性, 管理の容易さおよびSunの市場への影響力から，Jini は最近注目されている情報家電のネット ワークソフトウェアシステムの中核として有望視されている。

* Sun, Sun Microsystems, Jini 抢よびJavaはSun Microsystems, Incの衙槽または登録商標である。

[1] Sun Microsystems, Inc : Jini (TM) Connection Technology, http://www.sun.com/jini/

(滋賀県立大学 I学部 長谷英明) 